\title{
Identifying patients' support needs following critical illness: a scoping review of the qualitative literature
}

\author{
J. King ${ }^{1}$, B. O'Neill ${ }^{2}$, P. Ramsay ${ }^{3}$, M. A. Linden ${ }^{4}$, A. Darweish Medniuk ${ }^{5}$, J. Outtrim ${ }^{6}$ and B. Blackwood ${ }^{7 *}$ (1)
}

\begin{abstract}
Background: Intensive care survivors suffer chronic and potentially life-changing physical, psychosocial and cognitive sequelae, and supporting recovery is an international priority. As survivors' transition from the intensive care unit to home, their support needs develop and change.
\end{abstract}

Methods: In this scoping review, we categorised patients' support needs using House's Social Support Needs framework (informational, emotional, instrumental, appraisal) and mapped these against the Timing it Right framework reflecting the patient's transition from intensive care (event/diagnosis) to ward (stabilisation/preparation) and discharge home (implementation/adaptation). We searched electronic databases from 2000 to 2017 for qualitative research studies reporting adult critical care survivors' experiences of care. Two reviewers independently screened, extracted and coded data. Data were analysed using a thematic framework approach.

Results: From 3035 references, we included 32 studies involving 702 patients. Studies were conducted in UK and Europe $(n=17,53 \%)$, Canada and the USA $(n=6,19 \%)$, Australasia $(n=6,19 \%)$, Hong Kong $(n=1,3 \%)$, Jordan $(n=1$, $3 \%$ ) and multi-country $(n=1,3 \%)$. Across the recovery trajectory, informational, emotional, instrumental, appraisal and spiritual support needs were evident, and the nature and intensity of need differed when mapped against the Timing it Right framework.

Informational needs changed from needing basic facts about admission, to detail about progress and treatments and coping with long-term sequelae. The nature of emotional needs changed from needing to cope with confusion, anxiety and comfort, to a need for security and family presence, coping with flashbacks, and needing counselling and community support. Early instrumental needs ranged from managing sleep, fatigue, pain and needing nursing care and transitioned to needing physical and cognitive ability support, strength training and personal hygiene; and at home, regaining independence, strength and return to work. Appraisal needs related to obtaining feedback on progress, and after discharge, needing reassurance from others who had been through the ICU experience.

Conclusions: This review is the first to identify the change in social support needs among intensive care survivors as they transition from intensive care to the home environment. An understanding of needs at different transition periods would help inform health service provision and support for survivors.

Keywords: Critical illness, Qualitative research, Recovery, Scoping review, Support needs

\footnotetext{
* Correspondence: b.blackwood@qub.ac.uk

${ }^{7}$ Wellcome-Wolfson Institute for Experimental Medicine, School of Medicine,

Dentistry and Biomedical Sciences, Queen's University Belfast, 97 Lisburn

Road, Belfast BT9 7BL, Northern Ireland, UK

Full list of author information is available at the end of the article
}

C The Author(s). 2019 Open Access This article is distributed under the terms of the Creative Commons Attribution 4.0 International License (http://creativecommons.org/licenses/by/4.0/), which permits unrestricted use, distribution, and reproduction in any medium, provided you give appropriate credit to the original author(s) and the source, provide a link to the Creative Commons license, and indicate if changes were made. The Creative Commons Public Domain Dedication waiver (http://creativecommons.org/publicdomain/zero/1.0/) applies to the data made available in this article, unless otherwise stated. 


\section{Background}

The numbers of patients both admitted to and surviving intensive care (ICU) is increasing worldwide [1]. The physical, psychosocial and cognitive sequelae of critical illness, recently termed 'Post Intensive Care Syndrome' [2], is increasingly reported in the literature in terms of the chronicity and the impact on important patient-reported outcomes such as health-related quality of life [3], family life [4], social participation [5] and return to work [6]. This work has led to a growing international awareness of the need to support patients throughout recovery [7-9] towards survivorship [10-12]. For the purpose of this review, 'support needs' is defined as the additional help some adults need in order that they can live in the best way they can, despite any illness or disability they might have. They can be either short or long term, or can simply refer to the help required in getting through a difficult period.

Patients' support needs, are not routinely assessed or addressed during patients' ICU or acute hospital stay, and currently there are few evidence-based strategies for the translation of this increasing awareness into clinical practice [13]. Existing needs assessment questionnaires focus on a narrow or specific phase of ICU survivorship and there is limited evidence of their clinimetric or psychometric validity [14-18]. The issues are undoubtedly complex; nonetheless, a tool that could both capture patient need throughout the continuum of recovery and provide a mechanism for targeted support would be useful for the development or redesign of interventions, services or strategies.
Support needs assessment tools have been successfully developed for patient and carer populations for conditions such as cancer, traumatic brain injury and lung disease [19-21]. There are no available support needs assessment tools specifically designed for ICU survivors. In recent years, qualitative and mixed method approaches to exploring critical illness experiences has provided much needed insight into the recovery support needs from the perspectives of patients and family members. This paper describes the findings from a scoping review designed as a preliminary process towards developing such a tool for ICU survivors.

\section{Conceptual framework}

In this review, we used the Social Support Needs framework developed by House [22] to distinguish and categorise needs into four types of support (informational, emotional, instrumental, appraisal) as shown in Fig. 1. A priori, we agreed to report additional needs if identified. To categorise corresponding support needs across the recovery continuum, we mapped the identified needs onto the Timing it Right (TIR) framework. Originally developed to capture support needs of family members caring for a stroke survivor at key recovery transition phases [23], the TIR has also been used to explore the support needs of survivors of acute respiratory distress syndrome $[24,25]$. The TIR framework includes five phases of the continuum of care for ICU survivors as shown in Fig. 2.

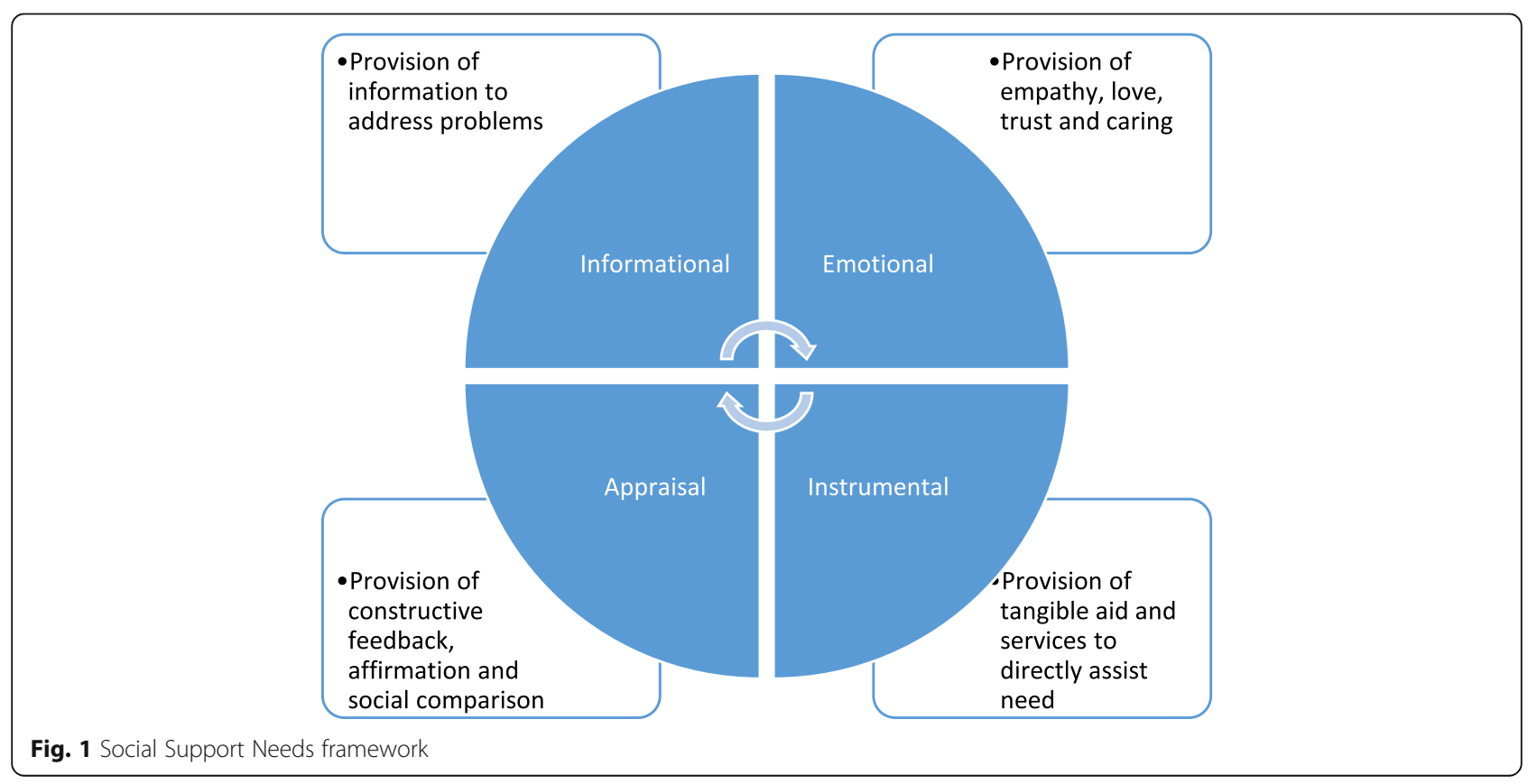




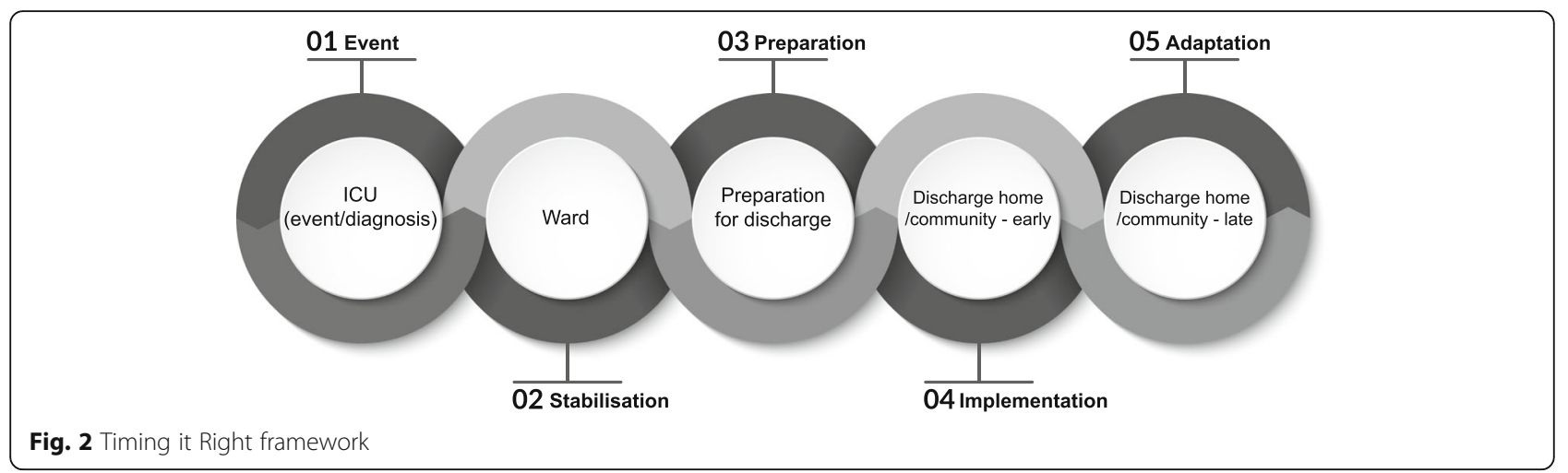

\section{Methods}

We developed a review protocol (Additional file 1) and reported the review according to the Preferred Reporting Items for Systematic reviews and Meta-Analyses extension for Scoping Reviews (PRISMA-ScR) [26]. We posed the following review questions: (1) what types of support do patients need following ICU discharge; (2) in what way do support needs differ across the continuum of recovery from ICU discharge to longer-term, communitybased recovery?

\section{Search strategy}

We conducted the search using key words formulated for each database [needs assessment, ICU survivorship, critical care, intensive care, qualitative research]. We searched key databases including Cumulative Index of Nursing and Allied Health Literature (CINAHL), MEDLINE, EMBASE (see Additional file 1). We limited the search from 2000 to April 2017 to capture contemporary healthcare provision.

We included qualitative research studies conducted with adult ICU patients. The phenomena of interest were patient-reported support needs that included, but were not restricted to, mental, emotional, psychological, cognitive and physical needs and resource needs such as educational and equipment needs. We included studies reporting needs at single or multiple time points after ICU discharge.

\section{Screening, data extraction and analysis}

Two reviewers (JK, ML) independently screened titles/ abstracts and full-text articles. JK and BB extracted data independently. We identified and extracted themes from eligible studies relevant to the phenomena of interest. Within the themes, we read, extracted and coded data references where authors described patient-reported needs. To ensure consistency of the coding process, data references were coded independently by two sets of three reviewers (JK and BB; JK and PR). Through discussion among the review team, we agreed that we had reached data saturation of themes and relevant codes were categorised into one of the four categories of the Social Support Needs framework and mapped against periods from the TIR framework [22, 23]. In keeping with the scoping review framework ethos, we did not apply study quality assessment [27].

\section{Results}

We identified 3035 papers. After removing duplicates and non-eligible studies, 32 studies were included in the review (see Fig. 3). Table 1 presents the study characteristics. Study type methods included phenomenology $(n=6)$, grounded theory $(n=4)$, interpretive $(n=1)$, descriptive/narrative $(n=16)$ and survey $(n=4)$. Sample sizes ranged from five to 222 , and the total number of participants in included studies was 702. Studies were conducted in the UK $(n=12,38 \%)$, Australia $(n=5,16 \%)$, the USA $(n=4,13 \%)$, Canada $(n=2,6 \%)$ and Sweden $(n=3$, $8 \%$ ); one study each (3\%) conducted in Denmark, France, Jordan, Hong Kong and New Zealand, and one multinational study with participants from Australasia, Canada, the UK and the USA. Studies reported data either at single or multiple time points spanning the trajectory from ICU to post-discharge greater than 6 months (see Table 2).

\section{Findings}

We report findings in the four categories of support (i.e. information, emotional, instrumental, appraisal) with reference to the phases of the TIR framework.

\section{Informational needs}

Informational needs changed across the care continuum from event/diagnosis (ICU admission) to the adaptation phase.

\section{Event/diagnosis (ICU admission)}

In ICU, patients' informational needs centred on the events surrounding the ICU admission, diagnosis, treatment and prognosis $[25,28]$. Reflecting the acuity of illness accompanied by prolonged use of sedation to facilitate treatment (e.g. mechanical ventilation) and the prevalence of delirium, patients reported memory loss 


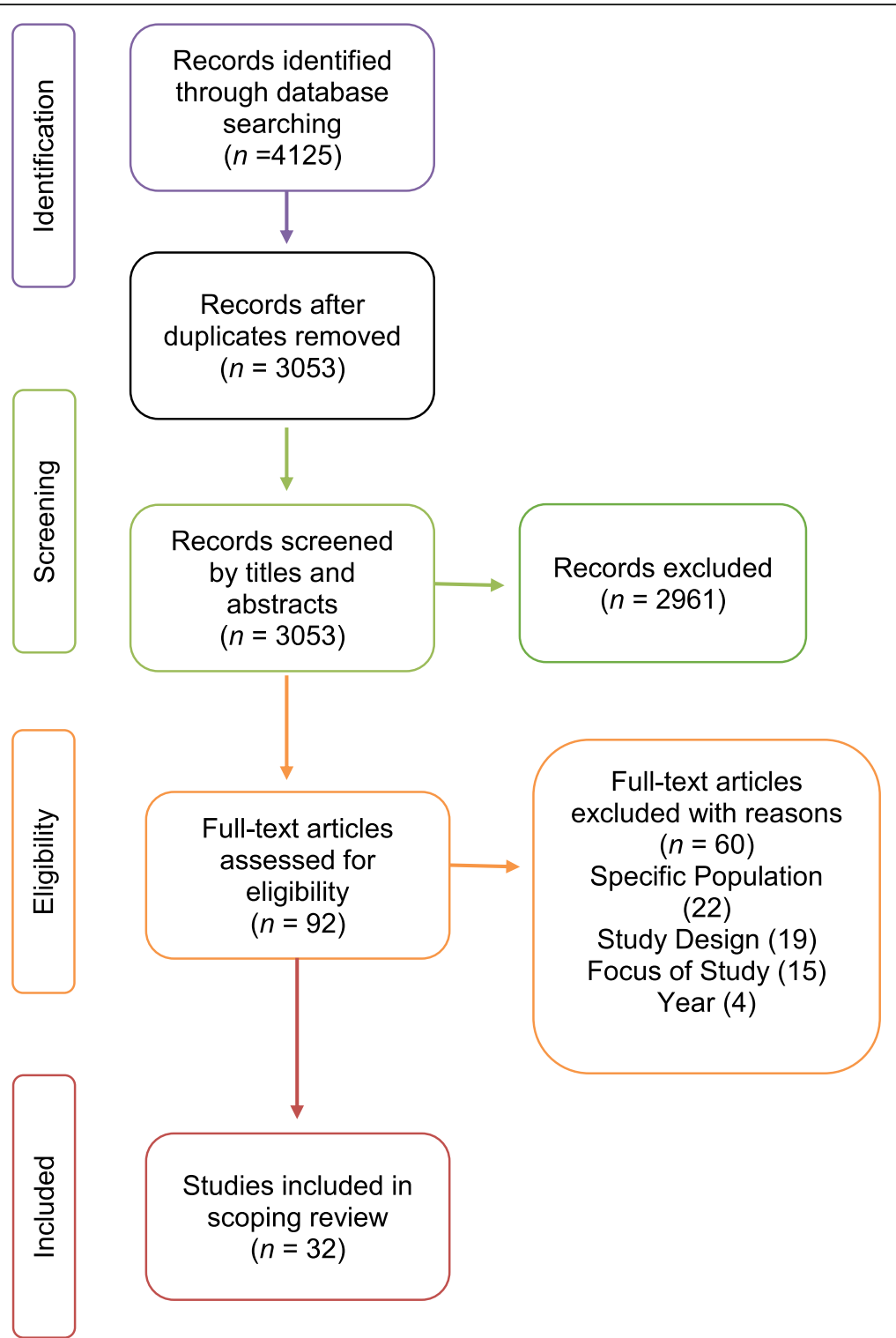

Fig. 3 Review flow chart

and a sense of being 'drugged' [24, 28-32]. Patients reported a need for information to enable them to understand the events surrounding their ICU admission and an understanding of their current health status, including their inability to speak and think clearly [24, 28]. Patients struggled, however, to integrate their own fragmented memories with factual information provided by ICU staff [28]. A key support need reported during this phase was for repeated transfer of clear, easily understandable information from healthcare staff to patients and families [25, 28].

\section{Stabilisation (ward care)}

The need for continued, clear communication was also apparent in the transition from ICU to the hospital ward. Patients reported a lack of communication between ICU and ward staff to facilitate continuity of care [33-35]. Although ICU discharge summaries were helpful, patients felt the information was too basic and needed more specific details, tailored to their unique presentation [33, 34, 36]. When information was provided, patients recalled periods of memory loss and not knowing where they were [36]. While some patients attributed this to not receiving information, others indicated that there was an element of forgetting because everything was 'blurred' and highlighted the need for continual repetition of information and orientation [37].

\section{Preparation (ward care)}

As patients progressed towards preparation for hospital discharge, their informational needs changed, to focus 
Table 1 Included study characteristics

\begin{tabular}{|c|c|c|c|c|c|c|}
\hline Study & Country & Time point focus & TIR Phase & $\begin{array}{l}\text { Sample } \\
\text { size } N= \\
702\end{array}$ & Approach and methods & Data collection timing \\
\hline $\begin{array}{l}\text { Abdalrahim } \\
2014\end{array}$ & Jordan & $\begin{array}{l}\text { Hospital discharge to 3- } \\
\text { months }\end{array}$ & Implementation & 18 & $\begin{array}{l}\text { Descriptive } \\
\text { Individual interviews }\end{array}$ & $\begin{array}{l}3 \text { month post hospital } \\
\text { discharge }\end{array}$ \\
\hline $\begin{array}{l}\text { Adamson } \\
2004\end{array}$ & Australia & ICU and hospitalisation & $\begin{array}{l}\text { Event/diagnosis; } \\
\text { stabilisation/ } \\
\text { preparation }\end{array}$ & 6 & $\begin{array}{l}\text { Descriptive } \\
\text { Individual interviews }\end{array}$ & $\begin{array}{l}6 \text { month post hospital } \\
\text { discharge }\end{array}$ \\
\hline Agard 2012 & Denmark & $\begin{array}{l}\text { First } 12 \text { months after D/C } \\
\text { from ICU }\end{array}$ & $\begin{array}{l}\text { Stabilisation/ } \\
\text { Preparation/ } \\
\text { implementation/ } \\
\text { Adaptation }\end{array}$ & 17 & $\begin{array}{l}\text { Grounded theory } \\
\text { Dyad interviews } \\
\text { (spouse and patient) } \\
\text { Focus group interviews }\end{array}$ & $\begin{array}{l}3 \text { and } 12 \text { months post ICU } \\
\text { discharge }\end{array}$ \\
\hline Bench 2011 & UK & ICU transfer to ward & Stabilisation & 11 & $\begin{array}{l}\text { Descriptive } \\
\text { Focus group interviews }\end{array}$ & $\begin{array}{l}\text { Variable from }<3 \text { months to } \\
\text { 3-years }\end{array}$ \\
\hline Bench 2014 & UK & ICU transfer to ward & Stabilisation & 42 & Survey & Prior to hospital discharge \\
\hline $\begin{array}{l}\text { Chaboyer } \\
2003\end{array}$ & Australia & $I C U$, ward and home & $\begin{array}{l}\text { Event/diagnosis; } \\
\text { stabilisation/ } \\
\text { preparation; } \\
\text { Implementation/ } \\
\text { adaptation }\end{array}$ & 222 & $\begin{array}{l}\text { Descriptive } \\
\text { Individual interview and } \\
\text { group meetings }\end{array}$ & $\begin{array}{l}\text { ICU, ward, 3, 6, 9, } 12 \text { months } \\
\text { post hospital discharge }\end{array}$ \\
\hline $\begin{array}{l}\text { Chaboyer } \\
2005\end{array}$ & Australia & ICU transfer to ward & Stabilisation & 7 & $\begin{array}{l}\text { Descriptive } \\
\text { Focus group interviews }\end{array}$ & $\begin{array}{l}1-2 \text { months post hospital } \\
\text { discharge }\end{array}$ \\
\hline $\begin{array}{l}\text { Chahraoui } \\
2015\end{array}$ & France & $\begin{array}{l}\text { ICU stay / current } \\
\text { psychological state ( } 3 \\
\text { months) }\end{array}$ & $\begin{array}{l}\text { Event/ diagnosis } \\
\text { stabilisation/ } \\
\text { preparation; } \\
\text { Implementation }\end{array}$ & 20 & $\begin{array}{l}\text { Survey/descriptive } \\
\text { Questionnaire/individual } \\
\text { interviews }\end{array}$ & $\begin{array}{l}3 \text { months post ICU } \\
\text { discharge }\end{array}$ \\
\hline $\begin{array}{l}\text { Chiang } \\
2011\end{array}$ & Hong Kong & $I C U$, ward and home & $\begin{array}{l}\text { Event/diagnosis; } \\
\text { stabilisation/ } \\
\text { preparation; } \\
\text { Implementation/ } \\
\text { adaptation }\end{array}$ & 6 & $\begin{array}{l}\text { Grounded theory } \\
\text { Individual interviews }\end{array}$ & $\begin{array}{l}\text { Variable, ICU, ward, and } 3 \\
\text { months post ICU discharge }\end{array}$ \\
\hline Cox 2009 & USA & ICU to home & $\begin{array}{l}\text { Event/diagnosis; } \\
\text { stabilisation/ } \\
\text { preparation; } \\
\text { Implementation/ } \\
\text { adaptation }\end{array}$ & 23 & $\begin{array}{l}\text { Phenomenology } \\
\text { Individual interviews }\end{array}$ & $\begin{array}{l}\text { Variable, } 3,9 \text {, or } 12 \text { months } \\
\text { post hospital discharge }\end{array}$ \\
\hline $\begin{array}{l}\text { Cypress } \\
2011\end{array}$ & USA & $\mathrm{ICU}$ & Event/diagnosis & 5 & $\begin{array}{l}\text { Phenomenology } \\
\text { Individual interviews }\end{array}$ & Ward \\
\hline $\begin{array}{l}\text { Czerwonka } \\
2015\end{array}$ & Canada & ICU, ward, home & $\begin{array}{l}\text { Event/diagnosis; } \\
\text { stabilisation/ } \\
\text { preparation; } \\
\text { Implementation/ } \\
\text { adaptation }\end{array}$ & 5 & $\begin{array}{l}\text { Descriptive } \\
\text { Individual interviews }\end{array}$ & $\begin{array}{l}\text { Variable, 3, 6, 12, } 24 \text { months } \\
\text { post ICU discharge }\end{array}$ \\
\hline $\begin{array}{l}\text { Deacon } \\
2012\end{array}$ & $\begin{array}{l}\text { USA, UK, } \\
\text { Canada, } \\
\text { Australia, NZ }\end{array}$ & $\begin{array}{l}\text { ICU and Post ICU } \\
\text { discharge }\end{array}$ & $\begin{array}{l}\text { Event/stabilisation/ } \\
\text { preparation; } \\
\text { Implementation/ } \\
\text { adaptation }\end{array}$ & 35 & $\begin{array}{l}\text { Survey } \\
\text { Questionnaire }\end{array}$ & $\begin{array}{l}\text { Unreported time, post } \\
\text { hospital discharge }\end{array}$ \\
\hline Field 2008 & UK & $\begin{array}{l}\text { ICU transfer to high } \\
\text { dependency unit/step } \\
\text { down or ward }\end{array}$ & Stabilisation & 34 & $\begin{array}{l}\text { Descriptive } \\
\text { Individual interviews }\end{array}$ & $\begin{array}{l}\text { Variable, post hospital } \\
\text { discharge }\end{array}$ \\
\hline $\begin{array}{l}\text { Haraldsson } \\
2015\end{array}$ & Sweden & $\begin{array}{l}\text { 2-month post ICU } \\
\text { discharge }\end{array}$ & Implementation & 12 & $\begin{array}{l}\text { Descriptive } \\
\text { Individual interviews / } \\
\text { diaries }\end{array}$ & 2 month post ICU discharge \\
\hline $\begin{array}{l}\text { Hupcey } \\
2000\end{array}$ & USA & $\ln I C U$ & Event/diagnosis & 14 & $\begin{array}{l}\text { Grounded theory } \\
\text { Individual interviews }\end{array}$ & In ICU or ward \\
\hline $\begin{array}{l}\text { Hupcey } \\
2001\end{array}$ & USA & In ICU & Event/diagnosis & 30 & $\begin{array}{l}\text { Descriptive } \\
\text { Individual interviews }\end{array}$ & In ICU or ward \\
\hline Jones 2003 & UK & ICU transfer to ward & Stabilisation & 18 & $\begin{array}{l}\text { Descriptive Case study } \\
\text { Individual interviews }\end{array}$ & $\begin{array}{l}\text { Within } 1 \text { week of ICU } \\
\text { discharge and } 6 \text { months } \\
\text { post ICU discharge }\end{array}$ \\
\hline
\end{tabular}


Table 1 Included study characteristics (Continued)

\begin{tabular}{|c|c|c|c|c|c|c|}
\hline Study & Country & Time point focus & TIR Phase & $\begin{array}{l}\text { Sample } \\
\text { size } N= \\
702\end{array}$ & Approach and methods & Data collection timing \\
\hline Lee 2009 & Canada & ICU, ward, home & $\begin{array}{l}\text { Event/diagnosis; } \\
\text { stabilisation/ } \\
\text { preparation; } \\
\text { Implementation/ } \\
\text { adaptation }\end{array}$ & 25 & $\begin{array}{l}\text { Descriptive } \\
\text { Individual interviews }\end{array}$ & $\begin{array}{l}\text { Approximately } 6 \text { years post } \\
\text { ICU discharge }\end{array}$ \\
\hline Lof 2008 & Sweden & Falling ill, ICU, ward & $\begin{array}{l}\text { Event/diagnosis; } \\
\text { stabilisation/ } \\
\text { preparation }\end{array}$ & 9 & $\begin{array}{l}\text { Descriptive } \\
\text { Individual interviews }\end{array}$ & $\begin{array}{l}3 \text { and } 12 \text { months post ICU } \\
\text { discharge }\end{array}$ \\
\hline $\begin{array}{l}\text { Maddox } \\
2001\end{array}$ & Australia & $\begin{array}{l}\text { Returning home from } \\
\text { hospital }\end{array}$ & Implementation & 5 & $\begin{array}{l}\text { Interpretative } \\
\text { Individual interviews }\end{array}$ & $\begin{array}{l}\text { 6-15 weeks post ICU } \\
\text { discharge }\end{array}$ \\
\hline $\begin{array}{l}\text { Magarey } \\
2005\end{array}$ & Australia & ICU & Event/diagnosis & 8 & $\begin{array}{l}\text { Survey/descriptive } \\
\text { Questionnaire / Individual } \\
\text { interviews }\end{array}$ & $\begin{array}{l}\text { Up to } 2 \text { years post ICU } \\
\text { discharge }\end{array}$ \\
\hline $\begin{array}{l}\text { McKinney } \\
2002\end{array}$ & UK & ICU transfer to ward & Stabilisation & 6 & $\begin{array}{l}\text { Phenomenology } \\
\text { Individual interviews }\end{array}$ & In ICU and in ward \\
\hline $\begin{array}{l}\text { Minton } \\
2005\end{array}$ & NZ & ICU, ward, home & $\begin{array}{l}\text { Event/diagnosis; } \\
\text { stabilisation/ } \\
\text { preparation; } \\
\text { Implementation }\end{array}$ & 6 & $\begin{array}{l}\text { Descriptive } \\
\text { Individual interviews }\end{array}$ & $\begin{array}{l}6 \text { months post ICU } \\
\text { discharge }\end{array}$ \\
\hline Odell 2000 & UK & ICU transfer to ward & Stabilisation & 6 & $\begin{array}{l}\text { Phenomenology } \\
\text { Individual interviews }\end{array}$ & Ward \\
\hline $\begin{array}{l}\text { Palesjo } \\
2015\end{array}$ & Sweden & ICU, ward, home & $\begin{array}{l}\text { Event/diagnosis; } \\
\text { stabilisation/ } \\
\text { preparation; } \\
\text { Implementation/ } \\
\text { adaptation }\end{array}$ & 7 & $\begin{array}{l}\text { Phenomenology } \\
\text { Individual interviews }\end{array}$ & $\begin{array}{l}\text { Up to } 2 \text { years post ICU } \\
\text { discharge }\end{array}$ \\
\hline $\begin{array}{l}\text { Pattison } \\
2015\end{array}$ & UK & $\begin{array}{l}\text { ICU and ongoing } \\
\text { recovery needs }\end{array}$ & $\begin{array}{l}\text { Event/diagnosis; } \\
\text { implementation }\end{array}$ & 22 & $\begin{array}{l}\text { Grounded Theory } \\
\text { Email interviews }\end{array}$ & $\begin{array}{l}2-4 \text { weeks or } 6 \text { months post } \\
\text { hospital discharge }\end{array}$ \\
\hline $\begin{array}{l}\text { Prinjha } \\
2009\end{array}$ & UK & $\begin{array}{l}\text { ICU follow-up care after } \\
\text { hospital discharge }\end{array}$ & $\begin{array}{l}\text { Implementation/ } \\
\text { adaptation }\end{array}$ & 34 & $\begin{array}{l}\text { Descriptive } \\
\text { Individual interviews }\end{array}$ & Post hospital discharge \\
\hline $\begin{array}{l}\text { Ramsay } \\
2013\end{array}$ & UK & ICU transfer to ward & Stabilisation & 20 & $\begin{array}{l}\text { Descriptive } \\
\text { Individual interviews }\end{array}$ & Post hospital discharge \\
\hline $\begin{array}{l}\text { Ramsay } \\
2016\end{array}$ & UK & $\begin{array}{l}\text { Post ICU discharge to } \\
\text { hospital discharge }\end{array}$ & Preparation & 14 & $\begin{array}{l}\text { Descriptive } \\
\text { Focus group interviews }\end{array}$ & $\begin{array}{l}>3 \text { months post ICU } \\
\text { discharge }\end{array}$ \\
\hline $\begin{array}{l}\text { Strahan } \\
2005\end{array}$ & UK & ICU transfer to ward & Stabilisation & 10 & $\begin{array}{l}\text { Phenomenology } \\
\text { Individual interviews }\end{array}$ & $3-5$ days on the ward \\
\hline $\begin{array}{l}\text { Williams } \\
2009\end{array}$ & UK & $\begin{array}{l}\text { Illness experience/critical } \\
\text { incident and its } \\
\text { aftermath }\end{array}$ & $\begin{array}{l}\text { Event/diagnosis; } \\
\text { stabilisation/ } \\
\text { preparation; } \\
\text { Implementation/ } \\
\text { adaptation }\end{array}$ & 5 & $\begin{array}{l}\text { Blended discourse, } \\
\text { narrative and } \\
\text { phenomenological } \\
\text { approaches } \\
\text { Individual interviews }\end{array}$ & $\begin{array}{l}\text { Early post hospital } \\
\text { discharge and } 1 \text { year later }\end{array}$ \\
\hline
\end{tabular}

on progress made since ICU discharge and the treatments and medications needed to ensure ongoing recovery [25]. The reported information needs continued to focus on the illness event and prognosis, as patients began to realise the nature, severity and short and long-term implications of their critical illness [25].

\section{Implementation/adaptation (discharge home)}

At home, information needs continued to focus on understanding their critical illness, but with a greater emphasis on coping with the long-term sequelae and stress. Return visits to the ICU, seeing the room they had occupied, and using an ICU diary were seen as beneficial by some patients in filling in the gaps, but not for others [38]. Patients wanted information delivered in a more permanent fashion, such as pamphlets or booklets for ongoing review [25]. Patients indicated a sense of wanting more information, but not knowing where to obtain it [24, 25]. They needed information and education to be extended to family members [39], particularly as questions about their experience and medical condition persisted long after returning to the community [24]. The need for the full 'story' was expressed by survivors to enable them to make sense of, and reclaim ownership of, their lives [28]. 
Table 2 Study reported time-periods according to the Timing It Right framework

\begin{tabular}{|c|c|c|c|c|c|}
\hline & Event/diagnosis (ICU & $\begin{array}{l}\text { Stabilisation } \\
\text { (ICU to ward) }\end{array}$ & $\begin{array}{l}\text { Preparation } \\
\text { (prior to hospital discharge) }\end{array}$ & $\begin{array}{l}\text { Implementation } \\
\text { (post-discharge up to } 6 \\
\text { months) }\end{array}$ & $\begin{array}{l}\text { Adaptation } \\
\text { (post-discharge greater than } \\
6 \text { months) }\end{array}$ \\
\hline \multicolumn{6}{|l|}{ Cypress 2011} \\
\hline \multicolumn{6}{|l|}{ Hupcey 2000} \\
\hline \multicolumn{6}{|l|}{ Hupcey 2001} \\
\hline \multicolumn{6}{|l|}{ Magarey 2005} \\
\hline \multicolumn{6}{|l|}{ Adamson 2004} \\
\hline \multicolumn{6}{|l|}{ Lof 2008} \\
\hline \multicolumn{6}{|l|}{ Chahraoui 2015} \\
\hline \multicolumn{6}{|l|}{ Pattison 2015} \\
\hline \multicolumn{6}{|l|}{ Chaboyer 2003} \\
\hline \multirow{2}{*}{\multicolumn{6}{|c|}{$\begin{array}{l}\text { Chiang } 2011 \\
\text { Cox } 2009\end{array}$}} \\
\hline & & & & & \\
\hline \multicolumn{6}{|l|}{ Czerwonka 2015} \\
\hline \multicolumn{6}{|l|}{ Deacon 2012} \\
\hline \multicolumn{6}{|l|}{ Lee 2009} \\
\hline \multicolumn{6}{|l|}{ Palesjo 2015} \\
\hline \multicolumn{6}{|l|}{ Williams 2009} \\
\hline \multicolumn{6}{|l|}{ Bench 2014} \\
\hline \multicolumn{6}{|l|}{ Chaboyer 2005} \\
\hline \multicolumn{6}{|l|}{ Field 2008} \\
\hline \multicolumn{6}{|l|}{ Jones 2003} \\
\hline \multicolumn{6}{|l|}{ McKinney 2002} \\
\hline \multicolumn{6}{|l|}{ Odell 2000} \\
\hline \multicolumn{6}{|l|}{ Strahan 2005} \\
\hline \multicolumn{6}{|l|}{ Ramsey 2013} \\
\hline \multicolumn{6}{|l|}{ Agard 2012} \\
\hline \multicolumn{6}{|l|}{ Ramsey 2016} \\
\hline \multicolumn{6}{|l|}{ Abdelrahim 2014} \\
\hline \multicolumn{6}{|l|}{ Haraldsson 2015} \\
\hline \multicolumn{6}{|l|}{ Maddox 2001} \\
\hline Prinja 2009 & & & & & \\
\hline
\end{tabular}

\section{Emotional needs}

\section{Event/diagnosis (ICU admission)}

Patients experienced a wide array of emotional reactions that changed over time. Recalled emotions prior to intubation in the ICU were terror, dread, uncertainty and facing imminent death $[31,40]$. Patients described regaining consciousness after a life-threatening condition as confusing, shattering and a feeling of emptiness [40]. Initial reactions included death anxiety $[5,28,31,32$, 40-43], feelings of loss of control [30, 37, 40], powerlessness [29], panic and abandonment [5, 44]. Fear and anxiety were common reactions to being physically restrained, endotracheal suctioning, chest physiotherapy, nasogastric tune insertion, the inability to communicate and having a tracheostomy [40, 41, 45].

Needs expressed during the early initial stages included the need for comfort [29] in words and touch [30] and the support of family [25, 28, 32, 44-47]. The need for family support and attendance extended across time. Within the ICU, knowing relatives could be contacted easily helped patients to develop a coping strategy [46] and the family support led to feelings of happiness and security [25].

\section{Stabilisation (ward care)}

Not surprisingly, the need that patients expressed for security and familiarity was often jeopardised when they transitioned from the familiar environment of the ICU to the new environment of the ward. Relocation anxiety was experienced by some patients when transferred to the ward [37], despite the presence of critical care outreach follow-up for some patients [35, 48]. Conversely, some patients experienced a sense of detachment, compliance and acceptance resulting in contentment: they had entered a chain of events over which they had no control [49]. Patients cited difficulty adjusting to the change from a one nurse to one patient ratio in the ICU to a lower nurse to patient ratio in the ward [49]. The ratio change caused patients to feel abandoned and vulnerable because of the loss of closer relationships with nurses [50,51] as well as feeling unimportant [50], isolated and neglected [51]. In addition, many patients felt depressed because of a perception of poor physical progress following transfer [35, 49].

\section{Implementation/adaptation (discharge home)}

Patients found the first few months after hospital discharge the most difficult and felt insecure about no longer being in the safe hospital environment [52]. Following discharge, vivid memories of ICU experiences involving terrifying dreams and flashbacks [41, 42, 50], and fear and worry about the complexities of their illness persisted for months [24, 25]. During this time, patients needed a lot of reassurance. Yet, one study reported that patients were reticent about seeking telephone support from ICU follow-up clinic nurses, even 
though the nurses had urged them to do so, due to a presumption that they were busy or had forgotten them [52]. The lack of contact resulted in some patients feeling abandoned after hospital discharge [52], and where scheduled follow-up ICU visits were provided, patients reported these were preceded with feelings of nervousness and tension brought on by unpleasant memories [38]. Follow-up sessions provided some security in allowing opportunity to ask questions and gain knowledge of their stay in the ICU [38].

Variability in the emotional experiences of survivors was common on discharge and was influenced by the availability of support at home. Patients with no primary caregivers experienced more anxiety and fear, while those with family members and support networks were more optimistic and positive about their discharge [25]. Furthermore, other patients felt a loss of role within the family and feelings of being dissociated and not involved in family decisions [5] and helplessness [53].

\section{Adaptation (discharge home)}

Patients' reported that their re-integration back into the community caused increased stress and was a source of depression [25]. Some expressed a sense of isolation as they avoided socialising, such as visiting relatives because it provoked unpleasant memories [5]. As a result, some patients expressed a need for mechanisms to allow an emotional outlet for themselves and their family members, including the support of community-based healthcare providers [25]. Across a few studies, patients felt that, unlike their physical health, their emotional and psychological health had received little attention and would have valued psychological counselling, more support from community-based healthcare providers and support in re-building psychological independence and confidence [25, 39, 46, 52]. Some patients reported they benefited from a support group where they had met others who truly understood the experience.

\section{Instrumental needs}

\section{Event/diagnosis (ICU admission)}

During their time in ICU, patients reported discomfort arising from a debilitating lack of sleep, noise, fatigue, pain and anxiety $[29,31,32,35,40,41]$. Key instrumental needs reported by patients were for personal care, hygiene and comfort, particularly relating to bathing, nutrition and pain relief $[31,54]$. As patients moved to the ward, they reported a need to progress from dependent to independent care, but needed adequate professional support to achieve that. Chiang et al. [46] summarised patients' views on needing structured continuity of care, such as that delivered by a critical care outreach service, and sufficient professional support before discharge home to the community. Additionally, patients in one study noted that they rarely experienced continuity of medical care [24].

\section{Stabilisation (ward care)}

Transferring from the ICU to the ward resulted in patients struggling to cope with basic care previously provided by nurses in the ICU $[49,51]$. Some patients assumed that they had to undertake their own basic care either because ward nurses were 'too busy' or because communication between the ICU and ward had broken down and ward staff were unaware of the patient's support needs [51]. Although some patients accepted they needed to be more independent on the ward, they still needed considerable physical help from either the staff $[33,35]$ or family carers [51].

\section{Implementation/adaptation (discharge home)}

A dominant theme across all TIR phases and particularly in the post ICU discharge period was the profound and disturbing physical and cognitive disability experienced by patients. For some, there were trauma-related disabilities such as loss of a limb or paralysis [41], loss of muscle strength and tone resulting in inability to stand [29], and decreased strength and endurance [24, 39]. Patients reported they struggled for independence to re-establish their premorbid physical strength $[40,55]$. Lesser-reported functional issues were problems with vision, speech and hearing [53]. Substantial, persistent cognitive deficits were also reported $[41,53,55]$, with a need for continued observation and support from caregivers to prevent harm due to patient forgetfulness [41]. Patients with cognitive impairment had to relearn performing basic behaviours in personal care and household activities; and at 1 year, goals shifted to higher level functioning such as planning, organisation, driving and returning to work [55].

Patients reported feelings of being a burden resulting from their lack of independence, and felt that their weakened state compromised their ability to lead a normal life [24]. Patients reported they needed physical support at home from community-based healthcare providers to assist them to become independent [25, 43]. They cited the need for earlier follow-up appointments where these were available, rather than months later [52]. Even after 1-year substantial training, many patients had not returned to their pre-ICU level of strength and activity [55].

Changes in living status due to increased reliance on support from family and friends, inadequate financial assistance and reduced family income were problems cited by some survivors [53]. Swedish patients also described the need for support from society to find appropriate work to prevent falling into financial difficulties with paying housing and hospital bills [43]. 


\section{Appraisal needs}

\section{Stabilisation (ward care)}

Appraisal needs were not evident during the ICU stay, but following transfer from ICU, many patients noted that ward staff knew little about them and therefore could not provide feedback on how they were progressing [51]. Some patients concluded this was due to lack of communication between the ICU and the ward [51]. Others expressed positive aspects of the transfer out of ICU; feeling this indicated an improvement in their recovery [37].

Following ICU discharge, patients could appraise how far they had come, citing feelings of doing well since their ICU stay [44, 45], and feeling special to have survived critical illness [42, 45]. In the study by Jones [42] which included only males, patients were able to identify their strong points and capitalise on them, but others failed to appreciate the mental and physical transformation required and how long this took after critical illness [41, 45]. Palesjo et al. [43] described the critical illness recovery process as a time when patients struggled to return to ordinary life, strived for reconciliation and learned to live in the moment in a changed body. In some cases, patients described their visible and invisible body marks as continuous reminders of their critical condition [43] and these often resulted in family relationship strain and change [41]. Life adjustment to the changes occurring after ICU required building up defence and coping mechanisms such as active coping, positive reframing, humour, acceptance, optimism, hope, self-sufficiency, goal-setting and spirituality $[41,44]$.

Patients stated they benefited from meeting others who had been through the ICU experience and understood the challenges they were addressing $[39,53]$. They expressed an overwhelming desire to know that what they experienced was 'normal', and that it took a long time and should not be concerned with slow progress $[38,39,52]$. Patients gained comfort from identifying with others' experiences, and this helped normalise their own experiences [53].

\section{Spiritual needs}

An additional category of spiritual support needs emerged from the literature and was not necessarily synonymous with religious needs. Three studies reported patients' views about having near death experiences and the need to believe in a higher entity [5, 32, 49]. A study conducted in Jordan reported survivors needing to thank and praise Allah for their recovery, making Dua (the act of supplication or asking Allah for help), and wishing to visit holy places to show obedience to Allah [5]. Similarly, Magarey and McCutcheon [32] reported that patients described a spiritual experience of moving from powerlessness to a sense of purpose and acceptance in their recovery. For some patients transferring from the ICU to the ward resulted in them realising that 'I could have died' [32, 49]. This traumatic realisation caused many participants to revisit the meaning of their lives and make each day count [49].

\section{Discussion}

This review has categorised ICU survivor support needs across the ICU patient recovery trajectory and has shown how they exist, change and adapt over time. Identifying and understanding the overwhelming emotional, physical and cognitive experiences, and the subsequent support needs expressed by people who have had a stay in ICU, is a powerful step towards determining early service intervention as patients make their journey from ICU to regaining independence at home.

Our scoping review confirms that patients' support needs are undoubtedly multifaceted and complex following critical illness. Patients express various needs at each transition point. In the early phases, instrumental and emotional needs come to the fore reflecting the fundamental human needs for nutrition, hydration, comfort, safety and physical and emotional support. Some support needs persisted and/or evolved across the continuum of recovery, depending upon the level of disability. If not addressed early on, these needs would likely continue and escalate in a later phase of recovery. As patients transitioned into different phases, their support needs followed the pattern of Maslow's hierarchy of needs [56]: requiring safety and security as they transitioned to the ward; needing family support and belonging and needing a sense of esteem as they transitioned towards increased independence from hospital care and the cotton wool blanket of family support. Although we used House's Social Support Needs framework to classify needs [22], we kept an open mind to capture additional needs. Spiritual needs emerged as an additional category in this population of patients which is unsurprising given the high mortality rates that have been reported in multinational cohort studies for patients during (19\%) and after (24\%) an ICU admission [57].

We consider the use of House's classification of needs with the addition of spiritual needs as highly relevant to this patient population. This view is supported by a recent study exploring contributory factors to early-unplanned hospital readmission of ICU survivors and recommending that interventions and service redesign include a strong focus on social support [58]. Contributory factors were inadequate informational (communication between secondary/primary care, hospital discharge planning, medication communication), emotional and spiritual (timing of psychological care, coming to terms with near-death experiences), instrumental (mobility 
issues and problems with specialist aids/equipment) and appraisal (fragile social support and goal setting) needs.

This review showed that patients were sometimes able to meet their own needs by drawing on previous life experience and this provided them with an element of 'appraisal' not captured by House's original definition, e.g. they showed ability to assess their own internal appraisal as opposed to receiving external appraisal from others [22]. Conceivably, ability to appraise may reflect self-efficacy or greater ability and motivation to manage their own recovery-a concept termed patient activation. While there are various methods for assessing aspects of activation, such as self-efficacy [59], health locus of control [60] and readiness to change [61], they focus on predicting single behaviours rather than the broader elements such as knowledge, skills, beliefs and motivation that a patient needs to manage a chronic illness [62].

Because support needs change at different stages of recovery, a method of identifying greatest need according to the patient's phase of recovery may help to target specific services at appropriate times. Developing a method, tool or questionnaire that could capture individual patient needs at any stage of recovery after ICU would be useful in clinical practice as this could help target care, strategies and services to support each individual and enable optimal provision of support to meet their changing needs. Additionally, services that are not yet available could be identified and established. While there has been consideration for needs assessment and needs-driven care in other populations (e.g. cancer care, coronary artery disease, interstitial lung disease) [63-65], we believe this review could inform a needs assessment tool or questionnaire for critical care survivors.

The strengths of our review include the use of identified frameworks for categorising support needs and recovery phases. The literature on ICU survivorship is quite large; therefore, we focused our search to include qualitative studies about patients' needs. We conducted our search only up to April 2017 and found there were repeating themes within the papers suggesting we had reached data saturation. Our assumption was confirmed by a recent study of contributory factors for readmission of ICU survivors reporting similar patient and system level themes [58].

\section{Conclusion}

Our review is the first to identify and summarise the changes in social support needs among intensive care survivors across the continuum from intensive care to the home and community environment. Patient needs are complex after ICU and should be assessed for each individual so that needs driven care and services can be appropriately provided to help recovery. Future research could consider the results from this review if developing a needs assessment tool for the critical care population.

\section{Additional file}

Additional file 1: Review protocol. (DOCX $24 \mathrm{~kb}$ )

Abbreviations

ICU: Intensive Care Unit; TIR: Timing it Right

\begin{abstract}
Acknowledgements
Not applicable.

Funding

The review was conducted with funding received from the Intensive Care Foundation Research Priority Award, UK.
\end{abstract}

Availability of data and materials

All data generated or analysed during this study are included in this published article and its supplementary information files.

Authors' contributions

$\mathrm{BON}$ and $\mathrm{BB}$ conceptualised the review; JK and ML conducted the search; JK and BB extracted the data; JK, BB and PR coded the qualitative data; and all authors contributed to the protocol development and the final manuscript. All authors read and approved the final manuscript.

Ethics approval and consent to participate

Not applicable.

Consent for publication

Not applicable.

Competing interests

The authors declare that they have no competing interests.

\section{Publisher's Note}

Springer Nature remains neutral with regard to jurisdictional claims in published maps and institutional affiliations.

\section{Author details}

${ }^{1}$ Faculty of Health Sciences, School of Rehabilitation Sciences, University of Ottawa, Ottawa, Canada. ${ }^{2}$ Centre for Health and Rehabilitation Technologies, INHR, Ulster University, Newtownabbey, Northern Ireland, UK. ${ }^{3}$ School of Health and Social Care, Edinburgh Napier University, Edinburgh, Scotland, UK. ${ }^{4}$ School of Nursing and Midwifery, Queen's University Belfast, Belfast, Northern Ireland, UK. ${ }^{5}$ Department of Anaesthesia, Southmead Hospital, North Bristol NHS Trust, Bristol, England, UK. 'Division of Anaesthesia, Department of Medicine, University of Cambridge, Cambridge, England, UK. ${ }^{7}$ Wellcome-Wolfson Institute for Experimental Medicine, School of Medicine, Dentistry and Biomedical Sciences, Queen's University Belfast, 97 Lisburn Road, Belfast BT9 7BL, Northern Ireland, UK.

Received: 8 January 2019 Accepted: 15 April 2019

Published online: 24 May 2019

\section{References}

1. Adhikari NK, Fowler RA, Bhagwanjee S, Rubenfeld GD. Critical care and the global burden of critical illness in adults. Lancet. 2010;376(9749):1339-46.

2. Rawal G, Yadav S, Kumar R. Post-Intensive Care Syndroms: an overview. J Transl Int Med. 2017:5(2):90-2.

3. Oeyen SG, Vandijck DM, Benoit DD, Annemans L, Decruyenaere JM. Quality of life after intensive care: a systematic review of the literature. Crit Care Med. 2010;38(12):2386-400.

4. van Beusekom I, Bakhshi-Raiez F, de Keizer NF, Dongelmans DA, van der Schaaf M. Reported burden on informal caregivers of ICU survivors: a literature review. Crit care. 2016;20:16. 
5. Abdalrahim MS, Zeilani RS. Jordanian survivors' experiences of recovery from critical illness: a qualitative study. Int Nurs Rev. 2014;61(4):570-7.

6. Hodgson $\mathrm{CL}$, Capell E, Tipping CJ. Early mobilization of patients in intensive care: organization, communication and safety factors that influence translation into clinical practice. Crit Care. 2018;22(1):77.

7. Elliott D, Davidson JE, Harvey MA, Bemis-Dougherty A, Hopkins RO, Iwashyna TJ. Exploring the scope of post-intensive care syndrome therapy and care: engagement of non-critical care providers and survivors in a second stakeholders meeting. Crit Care Med. 2014;42(12):2518-26.

8. Reay $\mathrm{H}$, Arulkumaran N, Brett SJ. Priorities for future intensive care research in the UK: results of a James Lind Alliance Priority Setting Partnership. J Intensive Care Soc. 2014;15(4):288-96.

9. Needham DM, Davidson J, Cohen H, Hopkins RO, Weinert C, Wunsch H. Improving long-term outcomes after discharge from intensive care unit: report from a stakeholders' conference. Crit Care Med. 2012:40(2):502-9.

10. Iwashyna TJ. Survivorship will be the defining challenge of critical care in the 21st century. Ann Intern Med. 2010;153(3):204-5.

11. Iwashyna TJ. Trajectories of recovery and dysfunction after acute illness, with implications for clinical trial design. Am J Respir Crit Care Med. 2012; 186(4):302-4.

12. Kean S, Salisbury LG, Rattray J, Walsh TS, Huby G, Ramsay P. Intensive care unit survivorship' - a constructivist grounded theory of surviving critical illness. J Clin Nurs. 2017;26(19-20):3111-24.

13. Govindan S, Iwashyna TJ, Watson SR, Hyzy RC, Miller MA. Issues of survivorship are rarely addressed during intensive care unit stays. Baseline results from a statewide quality improvement collaborative. Ann Am Thorac Soc. 2014;11(4):587-91.

14. Aro I, Pietila AM, Vehvilainen-Julkunen K. Needs of adult patients in intensive care units of Estonian hospitals: a questionnaire survey. J Clin Nurs. 2012;21(13-14):1847-58.

15. Rattray J, Johnston M, Wildsmith JA. The intensive care experience: development of the ICE questionnaire. J Adv Nurs. 2004;47(1):64-73.

16. Ramsay P, Huby G, Merriweather J, Salisbury L, Rattray J, Griffith D, Walsh T, Collaborators R. Patient and carer experience of hospital-based rehabilitation from intensive care to hospital discharge: mixed methods process evaluation of the RECOVER randomised clinical trial. BMJ Open. 2016;6(8):e012041.

17. Akerman E, Fridlund B, Ersson A, Granberg-Axell A. Development of the 3SET 4P questionnaire for evaluating former ICU patients' physical and psychosocial problems over time: a pilot study. Intensive Crit Care Nurs. 2009;25(2):80-9

18. Akerman E, Fridlund B, Samuelson K, Baigi A, Ersson A. Psychometric evaluation of 3-set 4P questionnaire. Intensive Crit Care Nurs. 2013;29(1):40-7.

19. Ewing G, Grande G. Development of a Carer Support Needs Assessment Tool (CSNAT) for end-of-life care practice at home: a qualitative study. Palliat Med. 2013;27(3):244-56.

20. Rotondi AJ, Sinkule J, Balzer K, Harris J, Moldovan R. A qualitative needs assessment of persons who have experienced traumatic brain injury and their primary family caregivers. J Head Trauma Rehabil. 2007;22(1):14-25.

21. Reigada C, Bajwah S, Ross J, Boland J, Wells A, Yorke J, Grande G, Hart S, Currow D, Papadopoulos T, et al. Adaptation, face and content validation of a palliative care needs assessment tool for people with interstitial lung disease. BMJ Support. 2015;5(1):111-2.

22. House JS: Work stress and social support: Reading, Mass. : Addison-Wesley Pub. Co., (1981.; 1981

23. Cameron Jl, Gignac MA. "Timing It Right": a conceptual framework for addressing the support needs of family caregivers to stroke survivors from the hospital to the home. Patient Educ Couns. 2008;70(3):305-14.

24. Czerwonka Al, Herridge MS, Chan L, Chu LM, Matte A, Cameron JI. Changing support needs of survivors of complex critical illness and their family caregivers across the care continuum: a qualitative pilot study of towards RECOVER. J Crit Care. 2015;30(2):242-9.

25. Lee CM, Herridge MS, Matte A, Cameron Jl. Education and support needs during recovery in acute respiratory distress syndrome survivors. Crit Care. 2009;13(5):R153.

26. Tricco AC, Lillie E, Zarin W, O'Brien KK, Colquhoun H, Levac D, Moher $D$, Peters MDJ, Horsley T, Weeks L, et al. PRISMA extension for scoping reviews (PRISMA-SCR): checklist and explanation. Ann Intern Med. 2018; 169(7):467-73.

27. Arksey H, O'Malley L. Scoping studies: towards a methodological framework Int J Soc Res Methodol. 2005;8(1):19-32.
28. Williams SL. Recovering from the psychological impact of intensive care: how constructing a story helps. Nurs Crit Care. 2009;14(6):281-8.

29. Adamson H, Murgo M, Boyle M, Kerr S, Crawford M, Elliott D. Memories of intensive care and experiences of survivors of a critical illness: an interview study. Intensive Crit Care Nurs. 2004;20(5):257-63.

30. Hupcey JE. Feeling safe: the psychosocial needs of ICU patients. J Nurs Scholarsh. 2000;32(4):361-7.

31. Lof L, Berggren L, Ahlstrom G. ICU patients' recall of emotional reactions in the trajectory from falling critically ill to hospital discharge: follow-ups after 3 and 12 months. Intensive Crit Care Nurs. 2008;24(2):108-21.

32. Magarey JM, McCutcheon HH. Fishing with the dead'--recall of memories from the ICU. Intensive Crit Care Nurs. 2005;21(6):344-54.

33. Bench SD, Day T, Griffiths P. Involving users in the development of effective critical care discharge information: a focus group study. Am J Crit Care. 2011;20(6):443-52.

34. Ramsay P, Huby G, Thompson A, Walsh T. Intensive care survivors' experiences of ward-based care: Meleis' theory of nursing transitions and role development among critical care outreach services. J Clin Nurs. 2013; 23(5-6):605-15.

35. Strahan EH, Brown RJ. A qualitative study of the experiences of patients following transfer from intensive care. Intensive Crit Care Nurs. 2005;21(3): 160-71.

36. Bench SD, Heelas K, White C, Griffiths P. Providing critical care patients with a personalised discharge summary: a questionnaire survey and retrospective analysis exploring feasibility and effectiveness. Intensive Crit Care Nurs. 2014 30(2):69-76.

37. Odell M. The patient's thoughts and feelings about their transfer from intensive care to the general ward. J Adv Nurs. 2000;31(2):322-9.

38. Haraldsson L, Christensson L, Conlon L, Henricson M. The experiences of ICU patients during follow-up sessions--a qualitative study. Intensive Crit Care Nurs. 2015;31(4):223-31.

39. Deacon KS. Re-building life after ICU: a qualitative study of the patients' perspective. Intensive Crit Care Nurs. 2012;28(2):114-22.

40. Minton C, Carryer J. Memories of former intensive care patients six months following discharge. Contemp Nurse. 2005;20(2):152-8.

41. Cox CE, Docherty SL, Brandon DH, Whaley C, Attix DK, Clay AS, Dore DV, Hough CL, White DB, Tulsky JA. Surviving critical illness: acute respiratory distress syndrome as experienced by patients and their caregivers. Crit Care Med. 2009;37(10):2702-8.

42. Jones $C$, Lyons $C$, Cunningham C. Life review following critical illness in young men. Nurs Crit Care. 2003;8(6):256-63.

43. Palesjo C, Nordgren L, Asp M. Being in a critical illness-recovery process: a phenomenological hermeneutical study. J Clin Nurs. 2015;24(23-24):3494-502.

44. Chahraoui K, Laurent A, Bioy A, Quenot JP. Psychological experience of patients 3 months after a stay in the intensive care unit: a descriptive and qualitative study. J Crit Care. 2015;30(3):599-605.

45. Maddox M, Dunn SV, Pretty LE. Psychosocial recovery following ICU: experiences and influences upon discharge to the community. Intensive Crit Care Nurs. 2001;17(1):6-15

46. Chiang VC. Surviving a critical illness through mutually being there with each other: a grounded theory study. Intensive Crit Care Nurs. 2011;27(6): 317-30.

47. Hupcey JE. The meaning of social support for the critically ill patient. Intensive Crit Care Nurs. 2001;17(4):206-12.

48. Pattison N, O'Gara G, Rattray J. After critical care: patient support after critical care. A mixed method longitudinal study using email interviews and questionnaires. Intensive Crit Care Nurs. 2015;31(4):213-22.

49. McKinney AA, Deeny $P$. Leaving the intensive care unit: a phenomenological study of the patients' experience. Intensive Crit Care Nurs. 2002;18(6):320-31.

50. Chaboyer W, Kendall E, Kendall M, Foster M. Transfer out of intensive care: a qualitative exploration of patient and family perceptions. Aust Crit Care. 2005;18(4):138-41 143-135.

51. Field K, Prinjha S, Rowan K. One patient amongst many': a qualitative analysis of intensive care unit patients' experiences of transferring to the general ward. Crit Care. 2008;12(1):R21.

52. Prinjha S, Field K, Rowan K. What patients think about ICU follow-up services: a qualitative study. Crit Care. 2009;13(2):R46.

53. Chaboyer W, Grace J. Following the path of ICU survivors: a qualityimprovement activity. Nurs Crit Care. 2003;8(4):149-55. 
54. Cypress BS. The lived ICU experience of nurses, patients and family members: a phenomenological study with Merleau-Pontian perspective. Intensive Crit Care Nurs. 2011;27(5):273-80.

55. Agard AS, Egerod I, Tonnesen E, Lomborg K. Struggling for independence: a grounded theory study on convalescence of ICU survivors 12 months post ICU discharge. Intensive Crit Care Nurs. 2012;28(2):105-13.

56. Maslow A. A theory of human motivation. Psychol Rev. 1943;50(4):370-96.

57. Capuzzo M, Volta C, Tassinati T, Moreno R, Valentin A, Guidet B, lapichino G, Martin C, Perneger T, Combescure C, et al. Hospital mortality of adults admitted to intensive care units in hospitals with and without intermediate care units: a multicentre European cohort study. Crit Care. 2014;18(5):551.

58. Donaghy E, Salisbury L, Lone NI, Lee R, Ramsey P, Rattray JE, Walsh TS. Unplanned early hospital readmission among critical care survivors: a mixed methods study of patients and carers. BMJ Qual Saf. 2018;27(11):915-27.

59. Lorig K. Outcome measures for health education and other health care interventions. Thousand Oaks: Sage; 1996.

60. Wallston KA, Stein MJ, Smith CA. Form C of the MHLC scales: a conditionspecific measure of locus of control. J Pers Assess. 1994;63(3):534-53.

61. Prochaska JO, Reading CA, Evers KE. The transtheoretical model and stages of change. In: FML KG, Rimer BK, editors. Health Behavior and Health Education. 2nd ed. San Francisco: Jossey-Bass; 1997.

62. Hibbard JH, Stockard J, Mahoney ER, Tusler M. Development of the patient activation measure (PAM): conceptualizing and measuring activation in patients and consumers. Health Serv Res. 2004;39(4 Pt 1):1005-26.

63. Richardson A, Medina J, Brown V, Sitzia J. Patients' needs assessment in cancer care: a review of assessment tools. Supportive Care Cancer. 2007: 15(10):1125-44.

64. Polikandrioti M, Goudevenos I, Michalis L, Nikolaou V, Dilanas C, Olympios C, Votteas $\mathrm{V}$, Elisaf $\mathrm{M}$ : Validation and reliability analysis of the questionnaire "needs of hospitalized patients with coronary artery disease. Health Sci J 2011, 5(2):137-148.

65. Boland JW, Reigada C, Yorke J, Hart SP, Bajwah S, Ross J, Wells A, Papadopoulos A, Currow DC, Grande G, et al. The adaptation, Face, and Content Validation of a needs assessment tool: progressive disease for people with interstitial lung disease. J Palliat Med. 2016;19(5):549-55.

Ready to submit your research? Choose BMC and benefit from:

- fast, convenient online submission

- thorough peer review by experienced researchers in your field

- rapid publication on acceptance

- support for research data, including large and complex data types

- gold Open Access which fosters wider collaboration and increased citations

- maximum visibility for your research: over $100 \mathrm{M}$ website views per year

At $\mathrm{BMC}$, research is always in progress.

Learn more biomedcentral.com/submissions 